\title{
Research on the Regulatory System of the PPP Infrastructure Project of the Government Based on the Green Perspective
}

\author{
Jie Sun ${ }^{1, a}$, Huijiang Gong ${ }^{2, b}$ and Lu Sun ${ }^{3, c}$ \\ ${ }^{1}$ School of Management, Tianjin University of Technology, Tianjin 300384, China \\ ${ }^{2}$ Project Department, Tianjin Wuqing District Construction Engineering Company First Construction \\ Company, Tianjin 301700, China \\ ${ }^{3}$ Planning Department, Tianjin Collection Pavilion Culture Development co., LTD, Tianjin 300142, \\ China \\ asyuan323@163.com, bonghuijiang123@126.com, cmu00bei@163.com
}

Keywords: The PPP mode, government regulation, regulatory mechanisms.

\begin{abstract}
Urban infrastructure construction and people's quality of life has a profound significance to the urban development. This article is based on the comparison of infrastructure PPP projects at home and abroad, from the perspective of green government is trying to build a perfect system of government regulation. Through a large number of references to related literature, this study was based on the PPP model city infrastructure construction, combined with the present situation of the regulatory system in our country. Don't forget to learn foreign outstanding regulatory way, embarks from the perspective of green in the regulatory way, regulatory content, regulatory process three aspects for the design of the government regulation system at the same time.
\end{abstract}

\section{Introduction}

With the continuous development of society, the government increased the investment in urban infrastructure, so the government had to introduce PPP model to relieve their financial pressure. Caused by a lack of government in the PPP project experience, which leads to the regulatory agencies, regulatory content and the way of regulatory are needed to improve, the inadequate strength of the project management lead to environmental quality declining, in this case, build the PPP infrastructure projects regulatory system is necessary.

This paper attempts to build a PPP model of the conceptual framework, from the government point of view of urban infrastructure PPP project. From the regulators, how to monitor, what these aspects of the analysis to build a complete regulatory system. This solves the problem that the market failure and the fund do not lead to the service quality and reduce the problem. Strengthen the PPP model in urban infrastructure construction and operation in China has played an important role. This will make a great contribution to the rapid development of China's economy.

\section{Literature Review}

\subsection{The Theory Review.}

Many scholars make a definition of the government regulatory through a lot of research from different perspectives. Although the definition is different but there are common features. Government regulation is the government according to the laws and regulations, through direct regulatory and management of enterprises into the market, price, product quality and services, to protect the legitimate rights and interests of enterprises and consumers, maintaining market order and ensure the stable operation of the market economy [1].

Project how to distinguish the theory from the role of public projects on the market's perspective, city public infrastructure project implementation is divided into non-operating items, quasi operational projects, and pure commercial projects. According to the project without business property and methods for fee collection to determine the investment subject, organization capital 
channel, operation and ownership model. Non-operating items free mechanism, need to be on behalf of the interests of the public government investment management, remuneration shall be owned by the government, the goal is to get social benefits and environmental benefits, such as city road, park. The quasi-operational project and charging mechanism of capital inflows, potential profits. Because of the policy and the influence of factors such as price, unable to recover the cost of projects, such as light rail, urban rail transport metro and rail [2]. Pure commercial charging mechanism of the project, is invested by the whole society, generally through the market allocation. The purpose is to pursue profit maximization, such as toll highway.

\subsection{Overseas Foreign Regulatory Pattern Contrast.}

Governments in public utilities regulatory differences mainly reflected in the following three aspects: the organization model of the regulatory agencies, the different regulatory agencies within the governance structure, price regulation [3].

Table 1 Differs from the foreign public utilities regulatory aspects

\begin{tabular}{|c|c|c|c|c|c|}
\hline \multirow{2}{*}{ Countries } & \multicolumn{2}{|c|}{ The organization mode of the regulator } & \multirow{2}{*}{$\begin{array}{l}\text { Regulators internal } \\
\text { governance structure }\end{array}$} & \multicolumn{2}{|c|}{ Price regulation } \\
\hline & Model & Characteristic & & Way & Characteristic \\
\hline Britain & $\begin{array}{c}\text { Layered } \\
\text { regulatory } \\
\text { model }\end{array}$ & $\begin{array}{l}\text { National level set a utility } \\
\text { regulator; regulator is } \\
\text { also set in place, no } \\
\text { subordinate relationship } \\
\text { between them. }\end{array}$ & Committee system & $\begin{array}{l}\text { Cost plus } \\
\text { Regulation }\end{array}$ & $\begin{array}{l}\text { The cost of an } \\
\text { enterprise is } \\
\text { based on the } \\
\text { price of a } \\
\text { reasonable } \\
\text { profit. }\end{array}$ \\
\hline Singapore & $\begin{array}{c}\text { The vertical } \\
\text { regulation } \\
\text { mode }\end{array}$ & $\begin{array}{l}\text { National level, and create } \\
\text { a national regulators, in } \\
\text { setting up several } \\
\text { branches, subordinate } \\
\text { relations. } \\
\text { State level set up } \\
\text { regulatory agencies, local } \\
\text { doesn't set. }\end{array}$ & $\begin{array}{c}\text { Personal } \\
\text { responsibility system }\end{array}$ & $\begin{array}{c}\text { Price cap } \\
\text { Regulation }\end{array}$ & $\begin{array}{l}\text { The price limit } \\
\text { is adjusted } \\
\text { according to } \\
\text { the time, the } \\
\text { inflation and } \\
\text { the technical } \\
\text { progress rate. }\end{array}$ \\
\hline
\end{tabular}

Table 2 The lack of infrastructure construction in our country the government regulatory system

\begin{tabular}{|c|c|c|}
\hline The shortage of the system & Reason & Performance \\
\hline $\begin{array}{l}\text { Lack of perfect social } \\
\text { regulatory system }\end{array}$ & $\begin{array}{l}\text { Urban residents' demands for } \\
\text { infrastructure. }\end{array}$ & $\begin{array}{l}\text { Public interest is likely to be in the } \\
\text { absence of security threats, unable } \\
\text { to meet the public interest [5]. } \\
\text { The control function of urban }\end{array}$ \\
\hline Legal system is not perfect & $\begin{array}{l}\text { There is no separate legal provision for } \\
\text { infrastructure PPP projects. }\end{array}$ & $\begin{array}{l}\text { infrastructure cannot be followed, } \\
\text { resulting in low efficiency of } \\
\text { government regulation [6]. }\end{array}$ \\
\hline $\begin{array}{l}\text { Lack of regulatory and } \\
\text { evaluation standards of } \\
\text { service quality and } \\
\text { scientific regulatory } \\
\text { method }\end{array}$ & $\begin{array}{l}\text { Quality regulatory and evaluation of the } \\
\text { quality of government services to the } \\
\text { private sector, and the handling of } \\
\text { illegal business practices. }\end{array}$ & $\begin{array}{l}\text { Regulators do not know what kind } \\
\text { of procedures in accordance with } \\
\text { the procedures for regulatory [7]. }\end{array}$ \\
\hline
\end{tabular}




\section{System Design}

\subsection{The Regulatory System in China.}

The application of PPP model has significantly increased at the same time, due to the late development of PPP model in our country, government regulatory system is not perfect, these problems greatly limits the PPP mode to play to its strengths effective. Only when we find the lack of the government regulatory system in the infrastructure construction in our country, can we make the corresponding measures in time, accelerate the development of our country [4].

\subsection{The Regulatory System of the PPP Infrastructure Project.}

This research mainly based on the perspective of green design regulatory system from three angles, respectively is how regulation and regulatory process, regulatory content, based on this put forward countermeasures and Suggestions to the government how to effective governance.

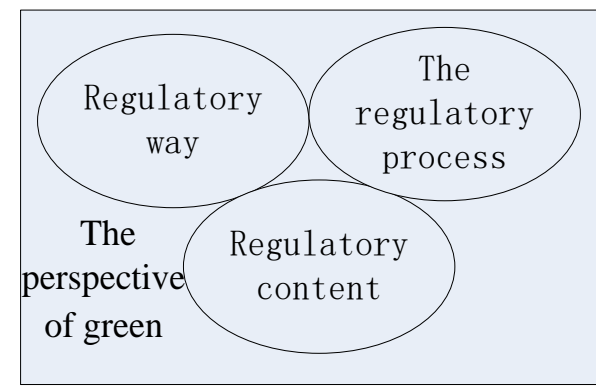

Fig. 1 Research idea

Establish reasonable government guarantee and commitment system. Government support and commitment system is aimed at investors (private companies), formulates preferential policies to increase government credit, attract social capital to participate in public infrastructure construction, promote the development of the PPP mode. Establish reasonable system of government support and commitment to good credit image, government, in turn, firm the confidence of the investors, promote the social capital investment, can effectively alleviate the lack of public infrastructure investment demands [8].

Establish market access system for public projects. Introducing market competition mechanism in the field of public projects, strictly according to the laws and regulations, establish a transparent and restrictions on private enterprises enter the condition, from the enterprise credit, enterprise scale, experience of qualification, capital and management ability, and social responsibility, evaluate according to law and transparent legal review, allowed to conform to the qualification of the enterprise of fair competition, implement the open tender, forming a full of competition, make the enterprise into the more efficient [9].

Improve the system of public project concession. Started in the project, construction, operation and handover of the entire process, perfect the corresponding franchising system, forming an orderly competition environment, avoid black-box and rent-seeking behavior of opportunity; In the project charter operation period shall practice a system of project interim evaluation, timely discover and correct the problems that arise in the process of operation for appeared during the period of serious violations, can practice the disclosure system and filing system [10].

Improve the system of project environmental protection. In the process of project implementation, focus on green environmental protection, for violations of enterprises regulatory increase the intensity of punishment, encouragement and regulatory at the same time, in the future let everyone remember the thought that everybody is responsible for protecting the environment.

\section{Summary}

This paper discusses the construction of government regulatory system in PPP mode based on the green perspective. However, this study also has many immature place, such as the one hand, it can be 
further discussed with the actual case. On the other hand, we can further explore the construction of the government regulatory system from the perspective of other perspectives.

\section{References}

[1]. Xiujuan Chen. The structure of the utility of new regulatory regime. Ji'nan: national news. Vol. 42 (2008).

[2]. Information on: www.oecd. Org /searchResult /0, 2665, en-33873 108-33873277-1-1-1-1-1-1, 00. html

[3]. Xiaowa Ye, Yan Feng. Chinese and foreign comparative study on the utility investment and financing mode of government function. Journal of building economy. Vol. 12 (2007), p. 44-46.

[4]. Junhao Wang. A number of China's infrastructure industry, government regulation reform thinking. Journal of economic research, Vol. 10 (1997), p. 36-42.

[5]. Lin Li, Shengshu Pan. The PPP project in Chongqing new regulatory system research. Cooperation in economy and technology. Vol. 06 (2011), p. 40-41.

[6]. Weiwei Song, Dequan Li. Construction market observation government regulatory problems. Journal of building economy. Vol. 08 (2004), p. 71-73.

[7]. Xiaopeng Li. The PPP project synergies between the government and private cooperation study. Journal of building economy. Vol. 12 (2004).

[8]. Hui Yu. Reinventing government regulators in China's infrastructure industry. Kunming: Journal of Yunnan University. Vol. 06 (2003).

[9]. Dongbo Wang, Wei Wang. Infrastructure projects the PPP mode selection research review. Project management technology. Vol. 12 (2013).

[10] Jinghua Li, Qiming Li. Analysis of economic risk factors in urban rail transit in China -- as an example of Taking Beijing metro line four. Journal of building economy. Vol. 10 (2007). 